Covered in: CrossRef; RePEC; CEEOL; Google Scholar.

\section{Social Reinsertion of Detainees - Only a Theoretical Concept?}

\section{Lavinia VIŞINARI ${ }^{1}$}

${ }^{1} \mathrm{MA}$, Faculty of Law and Administrative Sciences, "Ștefan cel Mare" University from Suceava, Romania.
Abstract: This article aims to discuss the reintegration of persons with a criminal record on the labor market and into society. Although the provisions of the law aim to reinstate these people back into society, the law also requires that the criminal record be presented when applying for a job in certain professions. Thus, the reintegration of persons with a criminal record into the labor market is limited by this requirement expressly provided by law. This article urges reflection on the importance of reintegration of former detainees on the labor market in order to prevent them from committing subsidiary criminal offences.

Keywords: rehabilitation of detainees; labour market; criminal record.

How to cite: Vişinari, L. (2019). Social Reinsertion of Detainees - Only a Theoretical Concept?. Journal of Mediation \& Social Welfare, 1(1), 57-63. doi:10.18662/jmsw/06 


\section{Introducere}

În opinia mai multor experți, este demonstrat că integrarea în piața muncii a foştilor deținuți este unul dintre principalii factori care contribuie la reducerea recidivei şi la reintegrarea socială a acestora. Solicitarea cazierului judiciar la angajare a devenit o practică pe care companiile ar trebui să o folosească cu circumspecție (Barreiro, n.d.). Este vorba, totuşi, de imposibilitatea unor persoane de a-şi satisface nevoile zilnice datorită dificultății în găsirea unui loc de muncă.

De asemenea, trebuie avut în vedere şi că imposibilitatea foştilor condamnați de se adapta la cerințele angajatorilor şi a societății în general poate să favorizeze apariția recidivei postcondamnatorii (Bulai, 1997). Persoanele eliberate din detenție fac parte din categoria grupurilor sociale vulnerabile, iar legislația în domeniul muncii pare să îngreuneze reintegrarea acestora în societate.

\section{Reintegrarea condamnaților. Principiu al procesului penal}

In doctrină se accentuează importanța pe care o are reintegrarea în muncă a foștilor condamnați pentru evitarea apariției recidivei (Dongoroz et al., 1970; Mitrache, 2017). Legea, însă, solicită expres depunerea unui cazier judiciar pentru angajarea pe anumite posturi. De asemenea, pentru unele funcții există condiția de angajare ca la predententul loc de muncă persoana să nu fi avut antecedente penale. Astfel, cele două izvoare ale dreptului, doctrina şi legea, nu se susțin una pe cealaltă în realizarea unei adevărate reintegrări a foştilor condamnați pe piața muncii şi în societate, în general.

\section{Perspectiva altor state asupra reintegrarii foştilor deținuţi în societate}

Un studiu în domeniul reintegrării ex-deținuților în piaţa muncii şi în societate finanțat de Comisia Europeană din 2003 defineşte reintegrarea ca „a-şi găsi locul într-un grup în afara penitenciarului” (Afouxenidis, Klee, \& Cavouriaris, 2003: 5). Pornind de la această definiție, țările din Europa au încercat să răspundă nevoii condamnaţilor de ,a-şi găsi locul” prin sisteme de reintegrare distincte.

Franţa se confruntă cu dificultăţi în ceea ce priveşte vârsta în momentul încarcerării şi durata detenției, aspecte ce fac dificilă reintegrarea foştilor condamnați în piața muncii. Intervenția instituțiilor statului în această problemă este minimă, iar nemulțumirile sunt legate de faptul că majoritatea planurilor şi proiectelor de reintegrare nu sunt puse în practică (Moldoveanu, 
2011). Franța se confruntă şi cu un deficit de asistenți sociali, fapt ce face ca deținuții să fie neinformați cu privire la programele de reabilitare, îngreunând accesul la informație şi defavorizând astfel procesul de reabilitare.

În Germania, însă, situația se prezintă altfel, identificându-se două programe de reintegrare socială. Programul MABis nu mai funcționează momentan, însă practica acestuia a fost de succes, asigurând locuri de muncă pentru 64,4\% dintre deținuți (EQUAL, n.d.). Programul „New Choises” îşi propune scaderea ratei recidivei şi reintegrarea condamnaţilor în societate. Acest program realizează o colaborare excelentă a instituțiilor din domeniul reintegrării, punând în practică şi recomandările făcute de foştii deținuți referitoare la problemele întâmpinate. Aici observăm o implicare a instituțiilor statului în reabilitare şi o colaborare între instituțiile statului, organizatorii programului şi foştii deținuţi, care aduce rezultate în ceea ce priveşte combaterea recidivei şi reintegrarea condamnaţilor în societate şi pe piaţa muncii (EQUAL, n.d.).

În ceea ce priveşte activitatea autorităților din Grecia în domeniul reabilitării persoanelor care au fost condamnate, se remarcă inactivitatea acestota, deşi există Codul Penitenciar Elen, în care sunt inserate o serie de reglementări, dar care nu sunt aplicate. De asemenea, nu există nicio politică de reintegrare profesională după eliberare (Moldoveanu, 2011).

Statele Unite ale Americii adoptă în 2012 un pachet legislativ nou numit „Ban the Box” care îşi propune să introducă o nouă practică a angajatorilor referitoare la situația foştilor condamnaţi. La nivel național, 35 de state şi peste 150 de oraşe au adoptat această politică (Agnan \& Starr, 2018), astfel încât în prezent angajatorii iau în considerare calificările candidatului la un loc de muncă fără stigmatul unei condamnări sau al înregistrării oficiale a stării anterioare de detenție. Aceste inițiative oferă solicitanților şanse egale pentru ocuparea forței de muncă, prin eliminarea întrebării privind istoricul de condamnare din cererile de angajare şi prin amânarea verificării acestor aspecte până când procesul de angajare devine mai avansat. Statele care au adoptat această politică sunt: Arizona (2017), California (2017, 2013, 2010), Colorado (2012), Connecticut (2016), Georgia (2015), Hawaii (1998), Illinois (2014, 2013), Indiana (2017), Kansas (2018), Kentucky (2017), Louisiana (2016), Maryland (2010), Michigan (2018), Minnesota (2013), Missouri (2016), Nebraska (2014), Nevada (2017), New Jersey (2014) (2016), Oklahoma (2016), Oregon (2015), Pennsylvania (2017), Rhode Island (2013), Tennessee (2016), Utah (2015), Washington (2018) şi Wisconsin (2016) (Agnan \& Starr, 2018). De asemenea, legislația din California, Connecticut, Hawaii, Illinois, Massachusetts, Minnesota, New Jersey, New Mexico, Oregon, Rhode Island, Vermont şi Washington 
prevede dreptul persoanelor condamnate la şanse egale în ceea ce priveşte ocuparea unui loc de muncă. Această practică legislativă a dus la mari progrese în procesul reabilitării persoanelor cu condamnări, dar şi în prevenția recidivei.

Situația foştilor condamnaţi din Israel este, de asemenea, un exemplu de bune practici. A fost organizată la nivel național Autoritatea pentru Reabilitarea Prizonierilor, înființată de către Avraham Hoffman în 1984 (Adler \& Avgar, n.d.). Aceasta îşi propune organizarea de programe înainte de eliberare (începute cu 3-6 luni înainte), cât şi după eliberarea din penitenciar. ARP face posibilă atât reintegrarea deținuților în societate, cât şi în piaţa muncii, dar pune accent mai ales pe starea psihică a deținutului. Astfel, activități precum cursuri parentale şi sfaturi pentru problemele de familie a deținuților căsătoriți sunt inițiate încă dinaintea eliberării, iar sprijinul real în găsirea unui loc de muncă şi organizarea diverselor organizații non-profit care să ajute la integrarea acestora în societate sunt activităţi realizate după eliberare (Adler \& Avgar, n.d.). Aceste activităţi, enumerate mai sus, sunt doar o parte dintre activitătile realizare de acest program. Observăm în Israel, mai pregnant decât în alte state, preocuparea autorităţilor cu privire la probemele întâmpinate de foştii condamnați, ceea ce duce la realizarea a mare parte dintre obiectivele stabilite.

\section{Probleme şi soluții pentru reintegrarea condamnaților în România}

Din punctul nostru de vedere, se doreşte reabilitarea cetățenilor care au condamnări penale, fără a sprijini însă consistent realizarea acesteia. În acest sens, chiar prin lege se solicită preyentarea cazierului judiciar pentru angajarea în anumite profesii. Existenţa unei condamnări în cazierul judiciar atrage scepticismul angajatorilor şi, totodată, poate anula şansele unui asemenea candidat la obținerea locului de muncă pentru care concurează. Pentru a se favoriza procesul reabilitării, se pot lua o serie de măsuri în această direcție. Se pot înființa programe de reabilitare, care să pună în relație directă angajatorul cu deținuții, având ca exemplu practica statelor europene. Se poate, de asemenea, crea o legislație specifică acestei probleme, asemănătoare cu legislația „Ban the Box” din SUA. In realitate societatea românească contemporană nu este suficient de deschisă la aceste schimbări, tendinţa spre punitivitate fiind dublată de cea de stigmatizare a foştilor condamnaţi. Corelând toate aceste elemente, se favorizează apetenţa pentru comiterea altei infracțiuni de către condamnat şi astfel ia amploare fenomenul recidivei. 
O altă soluție la care ar putea apela autorităţile statului este înființarea unor locuri de muncă destinate expres foştilor condamnați. Dacă în aceeaşi instituție ar lucra doar deținuți, nu s-ar realiza reintegrarea deplină a acestora în societate, contactul acestora cu societatea fiind limitat. Dorim să subliniem că modele de soluții în această direcție există, iar, față de opțiunea şomajului, este preferabil ca foştii condamnaţi să fie integraţi în muncă chiar şi într-un loc de muncă destinat expres condamnaţilor.

Există numeroase avantaje pe termen lung pe care le reprezintă angajarea pesoanelor care au fost private de libertate. În primul rând, angajarea foştilor condamnați poate fi o soluție care ar determina aducerea de plus-valoare la nivelul societății, pe mai multe direcții: asigurarea forței de muncă, reintegrarea acestei categorii defavorizate în societate şi, totodată, micşorarea şanselor de recidivă. În acest sens, am analizat raportul realizat pe baza unui chestionar aplicat deținuților, realizat la cererea Ministerului Justiţiei, de către Administrația Naţională a Penitenciarelor, în anul 2006. Raportul indică următorul aspect: „dorinţa persoanelor private de libertate de a fi dezvoltate perteneriate între sistemul penitenciar şi organizațiile guvernamentale sau neguvernamentale competente să ofere sprijin în vederea reintegrării” (MJ, 2006). Se observă că rata recidivei în România poate fi prevenită de instituțiile statului prin preocuparea pentru oferirea condițiilor necesare reintegrării sociale şi profesionale.

Pe de altă parte, intervine problema neinformării deținuților despre astfel de programe de reintegrare. Majoritatea condamnaților nu au cunoştinţă despre astfel de programe, fapt ce îngreunează procesul de reintegrare în piaţa muncii.

O problemă majoră, care, din păcate, în România este tratată superficial, este tratarea aspectelor ce țin de starea psihică a celui condamnat. Dincolo de dificultăţile cu care se confruntă în timpul arestului, dincolo de dificultăţile pe care cu siguranţă le va întâmpina la ieşirea din penitenciar, se află reținerile de ordon psihic ale unui condamnat care pot fi mai greu de combătut decât cele concrete, de ordin material. Apreciem că toate activitățile destinate reabilitării psihice a deținutului au influenţă directă asupra viitoarei sale conduite. De toate aceste activităţi ține prevenirea recidivei. În cele mai multe cazuri, recidiva postcondamnatorie intervine din cauza unor deprinderi care, în timpul detențiunii, în loc să fie corectate, s-au accentuat datorită lipsei consilierii, a lipsei practicării unor activităţi menite să realizeze o integrare mai facilă a acestora în societate. 


\section{Concluzii}

Din analiza de mai sus reiese că reintegrarea pe piaţa muncii a foştilor condamnaţi depinde în cea mai mare parte de politicile statale în privinţa acestora. Este o realitate evidentă, ce nu trebuie trecută cu vederea, deşi pe agenda publică sunt numeroase probleme considerate, poate, chiar mult mai importante. Pe lângă această lipsă de cooperare a autorităţilor cu potențiali angajatori, am identificat problemă importantă şi mentalitatea societății. $\mathrm{O}$ societate civilă care doreşte o schimbare a situației foştilor condamnați este o societate care ar acționa în acest sens, ar propune soluții. Judecata şi stigmatizarea pun piedici în procesul de reintegrare pe piaţa muncii a celor care, din diverse motive, au fost condamnați.

\section{References}

Adler, S. J., \& Avgar A. (n.d.). National labour law profile: The State of Israel. Retrieved from https://www.ilo.org/ifpdial/informationresources/national-labour-law-profiles/WCMS 158902/lang--en/index.htm

Afouxenidis, A., Klee, G., \& Cavouriaris, E. (2003). Field study of ex-convicts reintegration into labour market and social life. Retrieved from http://www.iaw.edu/tl files/dokumente/ex_convicts_part_one.pdf

Agan, A., \& Starr, S. (2018). Ban the Box, criminal records, and racial discrimination: A field experiment. The Quarterly Journal of Economics. 191-235. doi:10.2139/ssrn.2795795

Barreiro, S. (n.d.). What is a Ban-the-Box Law? Retrieved from https://www.nolo.com/legal-encyclopedia/what-is-a-ban-the-boxlaw.html

Bulai, C. (1997). Drept penal, partea generală [Penal law. General part]. Bucharest, Romania: All.

Dongoroz, V., Kahane, S., Oancea, I., Fodor, I., Iliescu, N., Bulai, C., Stănoiu, R., \& Roşca, V. (1970). Explicații teoretice ale Codului penal român [Theoretical explanations of the Romanian Penal Code] (2nd vol.). Bucharest, Romania: Editura Academiei Române.

European Commission, EQUAL. (n.d.). From prison to working life networking for a successful transition. Retrieved from https://ec.europa.eu/employment social/equal consolidated/data/docu ment/etg1-exa2-zubilis.pdf

Ministerul Justiției (MJ), Administrația Naţională a Penitenciarelor. (2006). Sondaj de opinie la nivelul persoanelor private de libertate din unitățile penitenciar. Raport de cercetare [Poll on detainees in prison units. Research report]. 
Retrieved from https://www.scribd.com/document/6163763/Cercetaredetinuti

Mitrache, C. (2017). Drept penal român. Partea generală [Romanian penal law. General part]. Bucharest, Romania: Hamangiu. 